\section{EPS Secretariats Reorganized}

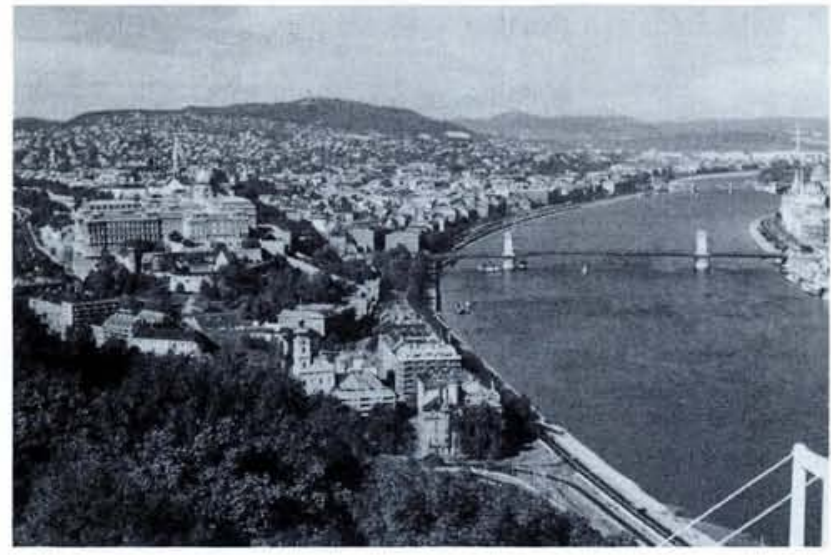

The consolidation of more of the Society's administrative work in the Budapest Secretariat (announced in Europhysics News 21 (1991) 136) and the accompanying transfer from Geneva of Gero Thomas, the Executive Secretary, on 1 January 1991 means that there will be some changes to contact points and organizational arrange ments. The Executive Secretary will have his office in the new Budapest Secretariat located on the second floor of a building ( $\boldsymbol{a}$ on map below) of the Hungarian Academy of Sciences, 7 Nádor utca (or Street) on the Pest side of the city centre. The Secretariat is close to the Atrium Hyatt Hotel (b) and the famous Lanchid (Chain) Bridge (c), and is only some five minutes by foot from the airport (and central) bus terminal (d).

All communications with Gero Thomas should pass through the Budapest Secretariat, even though some of his duties will require him to spend up to a week at a time in Geneva. Maria Làzàr, his very experienced, multilingual assistant who started work last month and is presently visiting Geneva to learn the ropes, will always know where he can be reached. A junior secretarial assistant will be hired as soon as a suitable candidate is found, while Livia Jenik, our former office manager in Budapest, will now act as an advisor in contacts with local authorities.

The management and staff editing of Europhysics Letters remains in Geneva along with its Staff Editors Christina Bouldin (who will continue to work half the time for EPS) and Edit Thomas in support, with Alicia Rowe as an assistant. The production of Europhysics News edited by Peter Boswell with Edit Thomas in assistance stays in Geneva. Paulina Aguiar, who started work last month as a junior assistant, will help deal with administrative work in Geneva as well as ensure the speedy transfer of information between the two Secretariats.

Generous support from the Central Research Institute for Physics in Budapest will continue to allow the Society's membership list to be maintained by the Institute's data processing department. The EPS meetings database will still be managed and located in Geneva.

Staff responsibilities are fairly clear-cut so there should be little confusion as the Secretariats (see table for full details) settle into their redefined rôles as shown on the left).

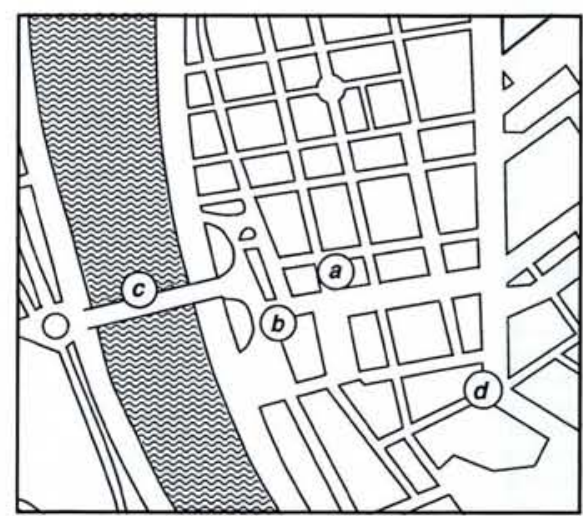

Nádor u. 7

H - 1051 Budapest

Hungary

Room 216, Acad. of Sci. Bldg Nádor u. 7

++36 (1) 1173510

++36 (1) 1176817

Livia Jenik

Maria Làzàr

Peter Boswell

Alica Rowe (EPL)

Edit Thomas

$\begin{array}{rr}8.30-12.00 & 8.30-12.30 \\ 13.30-17.30 & 13.15-16.45\end{array}$

$3.15-1$
G. Thomas

G. Thomas

P. Boswell

P. Boswel

C. Bouldin

A. Rowe

G. Thomas

Office hours: 